\title{
Afyon-Akșehir Grabeni Batı Kenarının Tektonik Özellikleri Üzerine Jeolojik ve Jeofizik Gözlemler: İki Evreli Genișleme Modeli Hakkındaki Tartıșmalara Bir Katkı
}

\author{
Geological and Geophysical Observations on the Tectonic Features \\ of Western Part of the Afyon-Akșehir Graben: A Contribution to the \\ Arguments on the Two-stage Extension Model
}

\section{SEVIL KAYA ${ }^{1,2,}$ KORHAN ESAT'1 , BERKAN ECEVITOĞLU ${ }^{3}$, VEYSEL IŞIK ${ }^{1}$, BÜLENT KAYPAK ${ }^{4}$, GÜLSEV UYAR ALDAŞ ${ }^{4}$, ASLI ZEYNEP CAN ${ }^{5}$, ESRA EZGI BAKSI ${ }^{6}$, ISMAIL AKKAYA ${ }^{7}$, GÜROL SEYITOĞLU1}

\author{
${ }_{1}^{1}$ Ankara Üniversitesi, Mühendislik Fakültesi, Jeoloji Mühendisliği Bölümü, Tektonik Araştırma Grubu, \\ 06100, Tandoğan, Ankara \\ 2 İ Afet ve Acil Durum Müdürlüğü, 74100, Merkez, Bartın \\ ${ }^{3}$ Anadolu Üniversitesi, Yer ve Uzay Bilimleri Enstitüsü, İki Eylül Kampüsü, 26555, Eskişehir \\ ${ }^{4}$ Ankara Üniversitesi, Mühendislik Fakültesi, Jeofizik Mühendisliği Bölümü, 06100, Tandoğan, Ankara \\ ${ }^{5}$ Maden Tetkik ve Arama Genel Müdürlüğü, Deniz ve Çevre Araştırmaları Daire Başkanlığı, 06800, \\ Çankaya, Ankara \\ ${ }^{6}$ Çevre ve Şehircilik Bakanlığı, Mekânsal Planlama Genel Müdürlüğü, Yerbilimsel Etüt Daire \\ Başkanlığı, 06510, Çankaya, Ankara \\ ${ }^{7}$ Yüzüncü Yıl Üniversitesi, Mühendislik-Mimarlık Fakültesi, Jeofizik Mühendisliği Bölümü, Zeve \\ Kampüsü, 65080, Van
}

\author{
Geliș (received) : 28 Ağustos (August) 2013 \\ Kabul (accepted) : 02 Nisan (April) 2014
}

Öz

Afyon-Akșehir Grabeni'nin batı kenarını olușturan, bașkalașım temel kayaçları ile Neojen çökel kayaçları arasındaki KB-GD doğrultulu tektonik dokanak bir grup araștırmacı tarafından Sultandağı Fayı olarak isimlendirilmiș ve ters fay olarak yorumlanmıș, diğer bir grup tarafından ise sınıın normal fay olduğu ileri sürülmüștür. Bazı araștırmacılar da Sultandağı Fayı'nı normal fay olarak kabul etmekle birlikte, bu fay tarafından kesilen daha eski Yakasenek Ters Fayı'nı tanımlamıșlardır. Bu çalıșmada söz konusu Yakasenek Ters Fayı üzerinde jeolojik ve jeofizik çalıșmalar gerçekleștirilmiștir. Temel birimler ile Neojen birimler arasındaki dokanak üzerinde uygulanan 'Sismik Ișın Yönlendirme' yöntemi ile Yakasenek Ters Fayı'na karșılık gelen tektonik hat kuzeydoğuya eğimli olarak belirlenmiștir. Buradaki fayın güneybatının aksine kuzeydoğuya eğimli olarak saptanması, bölgede Miyosen-Pliyosen'de sıkısmanın varı̆ğını ortaya koyan ve iki evreli graben modelini destekleyen Yakasenek Ters Fayı'nın bulunmadığını göstermiștir. Bölgede yapılan arazi gözlemlerinde de ters faya yönelik herhangi bir veriye rastlanmamıștır.

Anahtar Kelimeler: Afyon, Graben, Neotektonik, Normal fay, Sultandağı fayı, Yakasenek 
Yerbilimleri

\begin{abstract}
The NW-SE trending tectonic contact between the metamorphic basement and the Neogene sedimentary rocks, located at the western side of the Afyon-Akșehir Graben, is interpreted as a reverse fault and is named as the Sultandağı fault by some researchers. On the contrary, other workers claim that the Sultandağı fault is a normal fault. Some researchers define the Yakasenek reverse fault which is cut by the Sultandağı normal fault. In this study, the geological and geophysical studies have been performed on this tectonic contact. The tectonic contact that corresponds to the Yakasenek reverse fault was determined as a NE-dipping plane using with the 'Seismic Beam Steering' method. The identification of the NE-dipping plane instead of SW-dipping shows that the Yakasenek reverse fault, which is interpreted as a product of the Miocene-Pliocene contraction supporting two-stage graben model, does not exist. There is also no field evidence of reverse faulting in the area.
\end{abstract}

Keywords: Afyon, Graben, Neotectonics, Normal fault, Sultandağı fault, Yakasenek

\section{GiRiș}

Türkiye neotektoniği'nin esasları Șengör (1980) tarafından ortaya konmuștur. Bu klasik görüșe göre tektonik kaçma modeli (Șengör vd., 1985) neden-sonuç ilișkisine sahiptir. Modeli tetikleyen olay, GD Anadolu'da erken-Geç Miyosen'de Avrasya ve Arap Levhaları'nın çarpıșması olarak tanımlanmakta ve Türkiye'de neotektonik dönemin bașlangıcı olarak kabul edilmektedir. Tetiklemeyi izleyen evrede, Kuzey Anadolu ve Doğu Anadolu Fay Zonları'nın olușumu ile Anadolu Levhası'nın batıya hareket ettiği ve sonuçta Ege'de K-G yönlü genișlemeli tektoniğin Geç Miyosen'i izleyen dönemde geliștiği belirtilmektedir (Șengör vd., 1985). Bu modele göre Türkiye'nin neotektonik alanları Doğu Anadolu Sıkıșma Bölgesi, Orta Anadolu Ova Bölgesi ve Batı Anadolu Genișleme Bölgesi olarak tanımlanmıștır (Șengör, 1980; Șengör vd., 1985).

1990'dan sonra yapılan çalıșmalar Ege'deki K-G genișlemenin zamanlamasının en Geç Oligosen-Erken Miyosen olduğunu ortaya koyarak Türkiye'nin neotektonik çerçevesinde tektonik kaçma modelinde öne sürülen neden-sonuç ilișkisinin kurulamayacağını belirtmiștir (Seyitoğlu ve Scott, 1991; 1996).

Yakın zamanda meydana gelen depremlerden elde edilen odak mekanizması çözümleri ve yapılan çalıșmalar ıșığında Batı Anadolu Genișleme Bölgesi ve Orta Anadolu Ova Bölgesi arasındaki geçiș zonunun (Șengör vd., 1985) ayrıca incelenmesi gerekmektedir.

Batı ve Orta Anadolu'nun neotektonik özellikleri arasında bir ayrım da Barka ve Reilinger (1997;
Șek. 18) tarafından yapılmıș olup, bu makalede iki bölgeyi birbirinden Eskișehir Fayı ve FethiyeBurdur Fayı ayırmakta ve Orta Anadolu'nun K-G sıkıșma rejimi altında olduğu düșünülmektedir. Daha önceki araștırmacıların (Șengör vd., 1985) Batı ve Orta Anadolu arasında bir geçiş zonu önermelerinin nedeni Boray vd. (1985) tarafından Afyon-Akșehir Grabeni'nin batı kenarında tanımlanan Sultandağı Ters Fayı'dır (Șekil 1). Sultandağı Ters Fayı ile birlikte Tuzgölü Fayı'nın ters bileșeni (Șaroğlu vd., 1987) araștırmacılara Orta Anadolu'nun sıkıșmakta olduğu yönünde bilgi sağlamıștır (Șengör vd., 1985; Barka ve Reilinger, 1997). Diğer taraftan, Koçyiğit (1984)'in çalıșmasında geçiș zonundan bahsedilmediği ve Batı Anadolu genișlemeli yapılarının doğuya doğru Orta Anadolu'da Akșehir ve Tuzgölü Fayları'nda olduğu gibi devam ettiği görülmektedir (Koçyiğit, 1984; Șek. 4).

Türkiye'nin neotektonik çerçevesi üzerine yukarıda sözü edilen farklı yaklașımlar geçiș zonu olarak tanımlanan bölgede yer alan Afyon-Akșehir Grabeni'nde test edilebilir. Afyon-Akșehir Grabeni'nin batı kenarında yer alan Sultandağı Fayı bir ters fay olarak tanımlanmıștır (Boray vd., 1985; Șaroğlu vd., 1987; Öğdüm vd., 1989; 1991; Șaroğlu vd., 1992) ve Anadolu levhasının batıya hareketinin göstergesi olarak yorumlanmıștır. Bununla birlikte, bașka araștırıcılar aynı fayı normal fay olarak tanımlamıșlardır (Atalay, 1975; Demirkol vd., 1977; Koçyiğit, 1984).

Yakın zamanda ise Koçyiğit vd. (2000) melez bir model önererek ters ve normal fay gözlemlerini birleștirmiștir. Bu melez modele göre Afyon-Akșehir Grabeni'nin dolgulanması Erken Miyosen'de genișlemeli tektonik rejim altında 


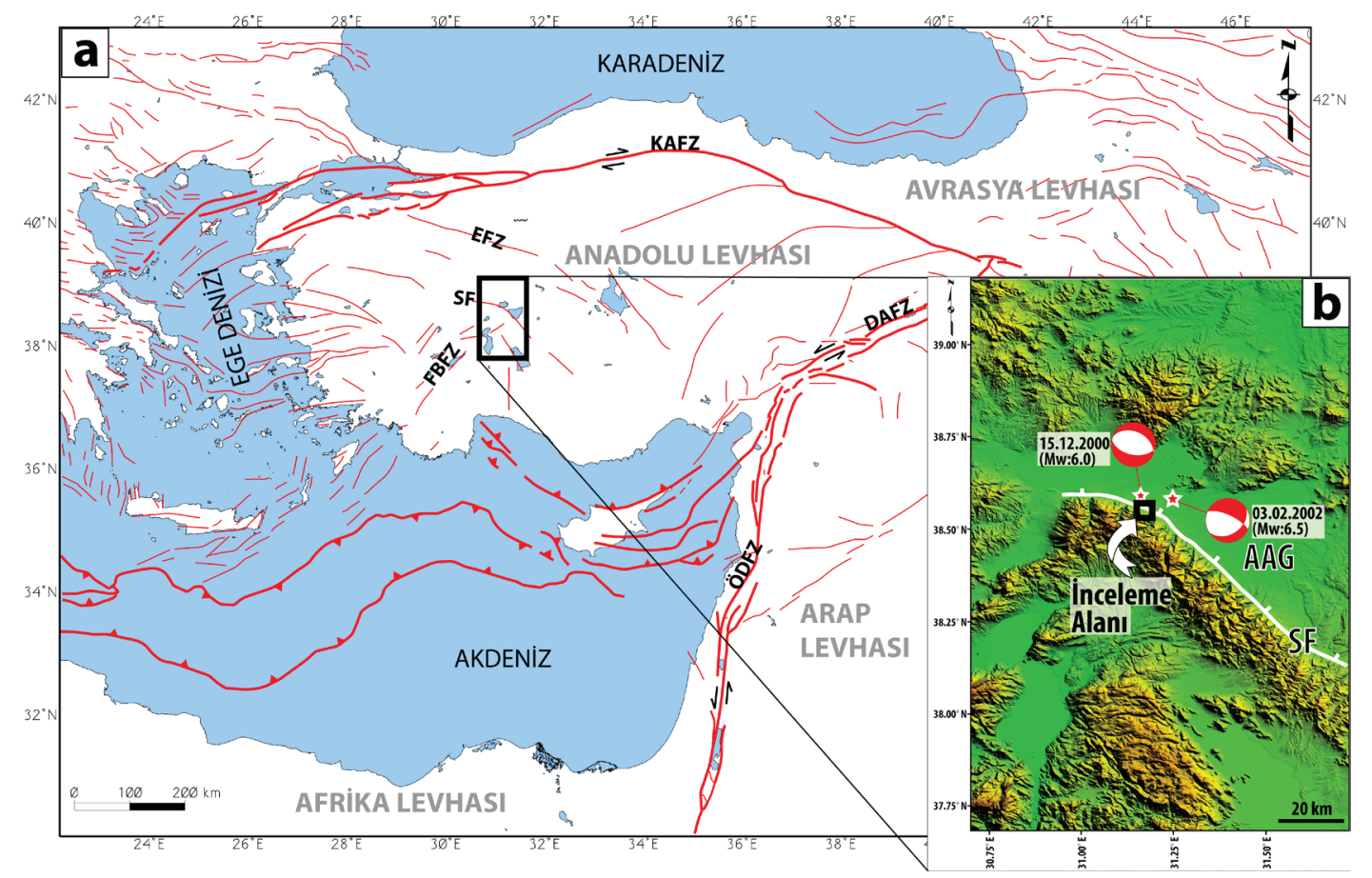

Șekil 1. a) Türkiye ve yakın çevresindeki ana neotektonik yapılar. Akdeniz'in jeodinamik haritasından yararlanılarak çizilmiștir (CCGM, 2013). DAFZ: Doğu Anadolu Fay Zonu, EFZ: Eskișehir Fay Zonu, FBFZ: Fethiye-Burdur Fay Zonu, KAFZ: Kuzey Anadolu Fay Zonu, ÖDFZ: Ölü Deniz Fay Zonu, SF: Sultandağı Fayı. b) Çalıșma alanı ve yakın çevresinin SRTM sayısal yükseklik modeli. İnceleme alanı siyah çerçeve ile gösterilmiștir. 15.12.2000 ( $M_{w}$ 6.0) ve 03.02.2002 ( $\left.M_{w} 6.5\right)$ depremlerinin odak mekanizması çözümleri sırasıyla Taymaz ve Tan (2001) ve Taymaz vd. (2002; Emre vd., 2003)'nden alınmıștır. AAG: Afyon-Akșehir Grabeni.

Figure 1.a) Major neotectonic structures in Turkey and surrounding regions. Redrawn using the geodynamic map of the Mediterranean (CCGM, 2013). DAFZ: East Anatolian Fault Zone, EFZ: Eskișehir Fault Zone, FBFZ: Fethiye-Burdur Fault Zone, KAFZ: North Anatolian Fault Zone, ÖDFZ: Dead Sea Fault Zone, SF: Sultandağı Fault. b) SRTM DEM image of the study area and its surroundings. Study area is indicated by black frame. Focal mechanism solutions of the 15.12.2000 $\left(M_{w} 6.0\right)$ and the 03.02.2002 $\left(M_{w} 6.5\right)$ earthquakes have been obtained by Taymaz and Tan (2001) and Taymaz et al. (2002; Emre et al. 2003), respectively. AAG: Afyon-Akșehir Graben.

gerçekleșmiștir. Geç Miyosen'de bir daralma fazı Yakasenek Ters Fayı'nı meydana getirmiș ve graben dolgusu deforme olmuștur. Kıvrımlanmıș graben dolgusu, yeni bir genișlemeli tektonik rejimde yataya yakın konumda çökelen Pliyo-Kuvaterner dolgu tarafından uyumsuzluk ile örtülmektedir (Koçyiğit vd., 2000). AfyonAkșehir Grabeni için önerilen bu melez model, Alașehir Grabeni için önerilen iki evreli genișleme modeli ile benzerlik göstermektedir (Koçyiğit vd., 1999). Bazı çalıșmalar iki evreli genișleme modeline karșı veriler sunarken (Seyitoğlu, 1999; Seyitoğlu vd., 2000; 2002; 2009; Seyitoğlu ve Ișık, 2009; Șengör ve Bozkurt, 2013), diğer çalıșmalar ise bu görüșü destekleyen veriler sunmușlardır (Koçyiğit vd., 2000; Koçyiğit ve Özacar, 2003; Koçyiğit, 2005; Bozkurt ve Rojay,
2005; Emre ve Sözbilir, 2007; Kaya vd., 2007).

Sultandağı Fayı'nın Neojen'den günümüze karakterini ve ilișkili tektonik rejimi açıklayan yukarıda bahsedilen bașlıca görüșler Șekil 2'de özetlenmiștir.

15.12.2000 Sultandağ $\left(M_{w}\right.$ 6.0) (Taymaz ve Tan, 2001; Özer vd., 2007) ve 03.02.2002 Çay $\left(M_{w}\right.$ 6.5) (Bașokur vd., 2002; Emre vd., 2003; Yürür vd., 2003; Ulusay vd., 2004; Akyüz vd., 2006) depremlerine ait odak mekanizması çözümlerinin normal faylanma vermesi Afyon-Akșehir Grabeni'ni sınırlayan fayın bir ters fay olduğu görüșünü (Boray vd., 1985) geçersiz kılmaktadır (Șekil 1). Diğer taraftan bu normal faylı odak mekanizması çözümleri ikinci evrede de genișleme öneren Koçyiğit vd. (2000) modeli ile bir 


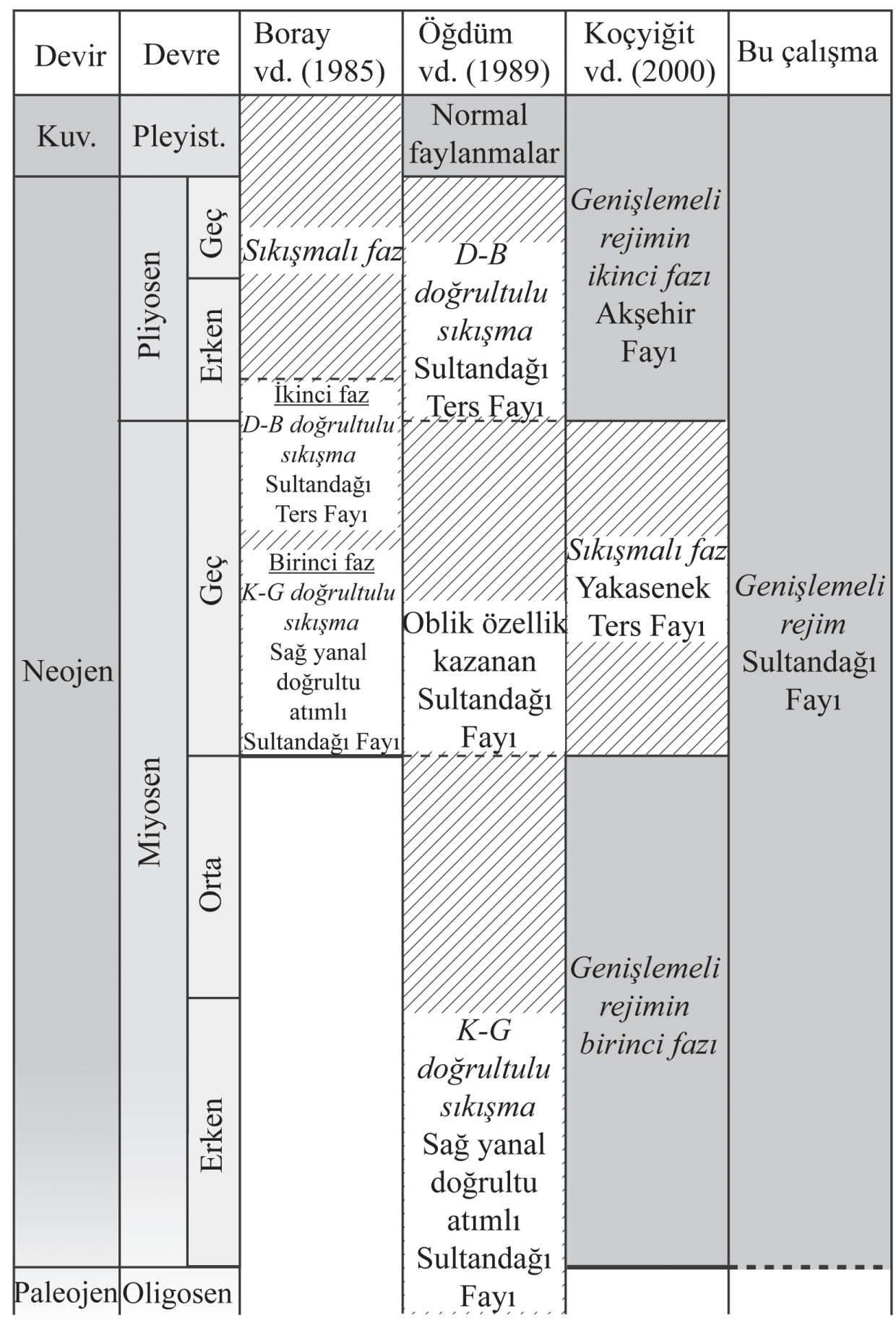

Șekil 2. Sultandağı Fayı'nın tektonik gelișimiyle ilgili bașlıca görüșler.

Figure 2. Main views on the tectonic development of the Sultandağı Fault.

çelișki olușturmamaktadır. Bu așamada önemli olan iki genișleme fazı arasında olduğu öne sürülen daralmalı fazın varlığının test edilmesidir. Bu nedenle Koçyiğit vd. (2000) çalıșmasında gözlenen Yakasenek Ters Fayı'nın bulunduğu Yakasenek Köyü'nün güneydoğusu tekrar ha- ritalanmıștır. Arazide yaptığımız jeolojik gözlemleri sınamak amacıyla aynı alanda bir sismik yansıma çalıșması da yapılmıștır. Bu makalede verilerimiz sunulduktan sonra bunların Türkiye'nin neotektonik çerçevesi üzerindeki etkileri tartıșılacaktır. 


\section{JEOLOJiK VE JEOFIZIK ÇALIȘMALAR}

\section{Afyon-Akșehir Grabeni Batı Kenarı: Sultandağı Fayı}

Sultandağı Fayı, Afyon-Akșehir Grabeni'nin güneybatı kenarında Kambriyen-Eosen yașlı bașkalașım kayaçları (Güngör, 2013) ile Neojen-Kuvaterner birimlerini ayırır. Fay, egemen olarak KB-GD doğrultulu olup kuzeybatı ucunda dönerek yaklașık D-B doğrultusunda uzanır (Șekil 1). Bu bölümde Sultandağı Fayı'nın çalıșma alanında yer alan bölümü üzerindeki arazi gözlemleri anlatılacaktır.

Sultandağı Fayı inceleme alanında KB-GD ve BKB-DGD doğrultusunda ve normal fay geometrisindedir (Șekil 3). Yüksek açıda ve KD ile KKD eğimlidir. Belirgin bir kayma düzlemi görülememesine karșın fayın taban bloğunu Geç Devoniyen-Karbonifer yașlı (Öcal vd., 2011) bașkalașım kayaçlar, tavan bloğunu ise Neojen-Kuvaterner havza çökelleri olușturur (Șekil 3 ve 4). Bu birimler mikromemeli fosiller yardımı ile yașlandırımıș olup, uyumsuz dokanaklı dört birime ayrılmıștır (Koçyiğit vd., 2000) (Șekil 5).

Bașkalașım kayaçları egemen olarak mermer/ rekristalize kireçtașları ile șist ve fillit litolojilerinden olușur. Șist/fillit türü kayaçlarda foliyasyon belirgindir. Düșük dereceli metamorfizma sunan bu kayaçlar metamorfizma sonrası deformasyona bağlı yaygın kıvrımlanma ve eksen düzlemi klivajı da gösterir. Fayın tavan bloğunda yer alan Neojen birimleri ise konglomera ve konglomeratik kumtașı ile daha kuzeydoğuda gölsel kireçtașı litolojileri ile temsil olur. Kırıntılı birimlerin egemen çakıl litolojisini mermer/rekristalize kireçtașları olușturur. Daha az oranda diğer bașkalașım kayaç taneleri gözlenir. Tanelerdeki yuvarlaklașma köșeliden iyi yuvarlaklașmaya kadar değișmektedir. Birim genelde iyi tutturulmuș olup kalın tabakalanma sunar. Kuvaterner birimlerini alüvyonlar olușturur.

Fayın etkileri en belirgin olarak temel kayaçlarda izlenmektedir. Temel kayaçlar fay izinden itibaren bir kaç on metre genișliğinde bir zon boyunca yaygın kırıklanma ve alterasyon gösterir. Kırıklanmıș/parçalanmıș mermer ve șist/fillitler kohesif olmayan breșleșme gösterir. Bu breșleșmeler yersel kohesif özellikte de olabilmektedir. Zon içerisinde yüksek eğimli çatlak gelișimi yanında küçük ölçekli kayma sunan makaslama kırıkları da bulunmaktadır. Zon boyunca kırmı- zımsı turuncu alterasyon rengi dikkat çekicidir. Fayın tavan bloğunda yer alan Neojen çökellerinde faylanmayı temsil eden deformasyon olușumları da zon içerisinde gözlenir. Sıkı bağlanmalı konglomera birimi yersel gevșek/zayıf bağlanmalı karaktere dönüșmüștür. Ayrıca Neojen birimi içerisinde de ana faya paralel/yarı-paralel normal fay gözlenmektedir (Șekil 3a ve 6). Bu faylanmayla ilișkili yersel kayma düzlemi gelișimi de bulunmaktadır (Șekil 7). $\mathrm{K} 25^{\circ} \mathrm{B}, 50^{\circ} \mathrm{KD}$ konumlu kayma düzlemi tipik kinematik belirteç göstermese de kuzeydoğuya eğimli bu fay, Sultandağı Fayı'nın genel karakteri de düșünüldüğünde normal fay olarak değerlendirilmiștir.

Ayrıntılı sedimantolojik çalıșmalar bulunmamakla birlikte Sultandağı Fayı'nın Neojen yașlı birimleri kontrol ettiği veya hemen sonrasında geliștiği düșünülmektedir. Șekil 6'da A-A' hattı boyunca GB-KD doğrultusunda alınmıș jeolojik kesit görülmektedir. Sultandağı Fayı, Yakasenek Kasabası'nın batı tarafında KD-GB doğrultusunda bir miktar yer değiștirmeye uğrayarak KB yönündeki gidișine devam eder. Ayrıca, kuzeye eğimli olan Neojen tabakaları çalıșma alanının bu kesiminde güneye doğru eğimlenmiș ve tabakaların eğim miktarları artmıștır. Bu verilerden hareketle bölgede olası bir sol yanal transfer fay haritalanmıștır (Șekil 3a).

Çalıșma alanında bașkalașım kayaçlarından kopup gelen rekristalize kireçtașı bloklarının olușturduğu oldukça geniș bir heyelan alanı tespit edilmiștir (Șekil 3a). Temele ait rekristalize kireçtașı blokları yamaç boyunca vadi içerisine kadar ilerlemiștir (Șekil 8). Heyelan alanının üzerinde yetișkin çam ağaçlarının düșey doğrultuda olması heyelanın oldukça eski olduğuna ișarettir. Bununla birlikte heyelanın taç kısmı bugünkü topoğrafya değișikliği ile kolayca izlenebilmektedir. Bu heyelanlı alanın topuk bölümünün, temel kayalarının Neojen birimler üzerinde yer alması nedeniyle önceki araștııııılar tarafından Yakasenek Ters Fayı olarak haritalanmıș olabileceği düșünülmektedir (Șekil 3b, Koçyiğit vd., 2000; Koçyiğit ve Özacar, 2003).

\section{Yakasenek Ters Fayı Olarak Tanımlanmıș Bölgede Gerçekleștirilen Sismik Yansıma Çalıșması}

Daha önceki araștırıcıların Yakasenek Ters Fayı olarak tanımladığı, bașkalașım kayaçları 

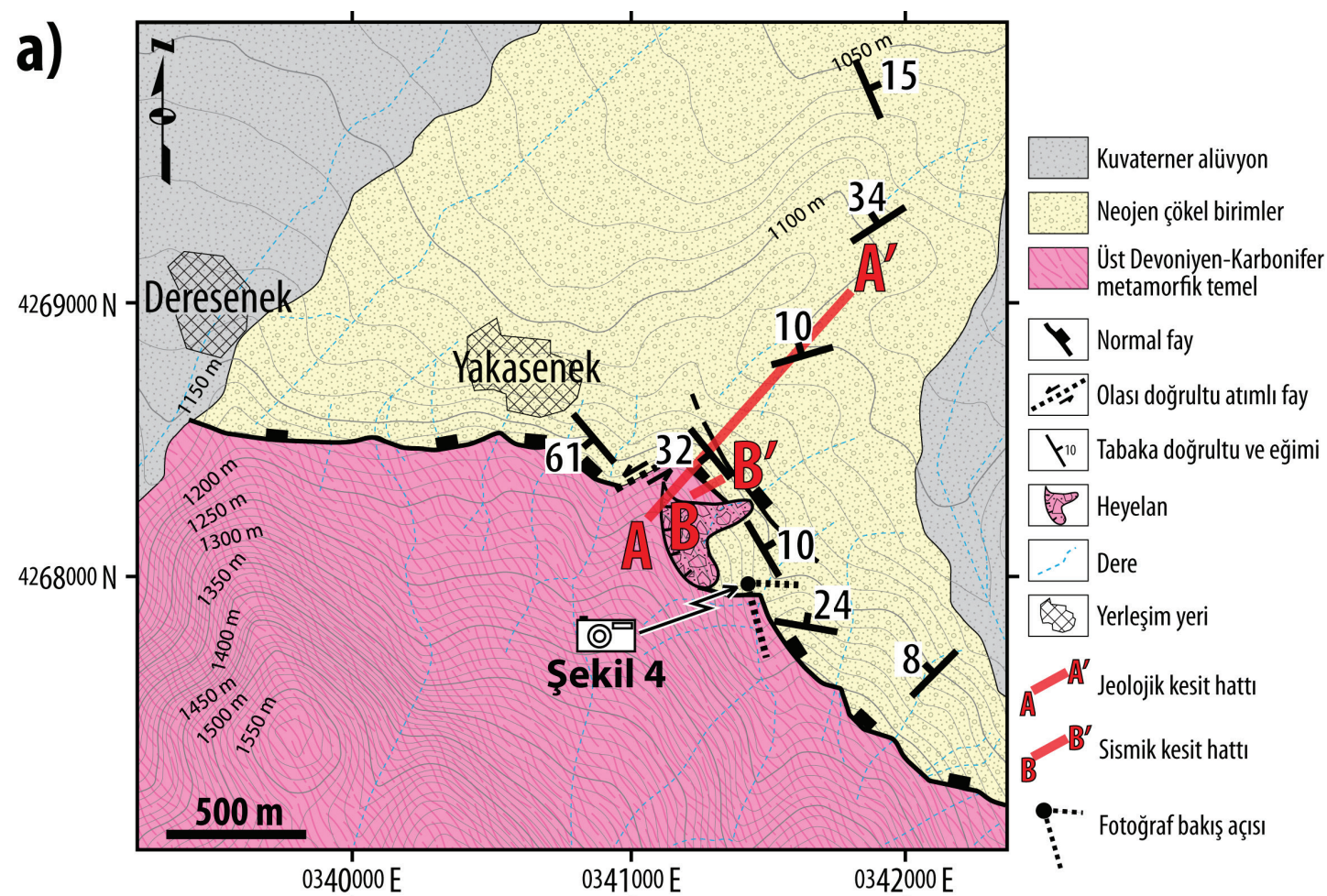

b)

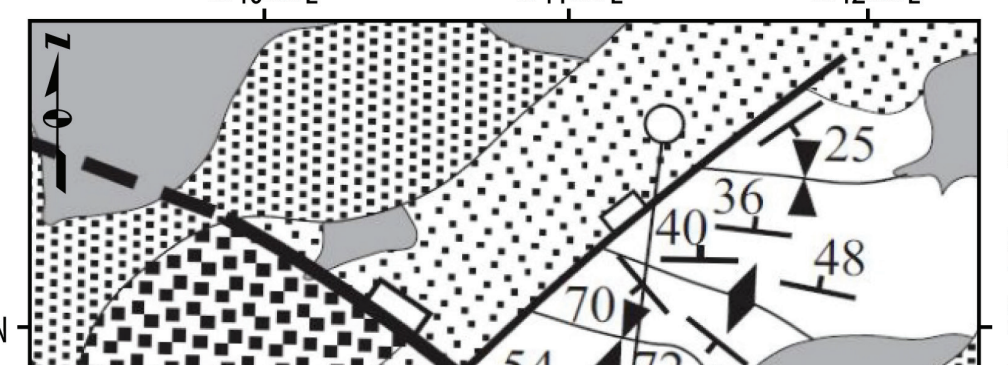

Alüvyal yelpaze
$\therefore \therefore$ Kuvaterner çökelleri

$4269000 \mathrm{~N}$
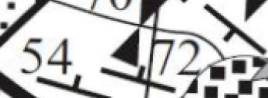

72: Pliyosen çökelleri

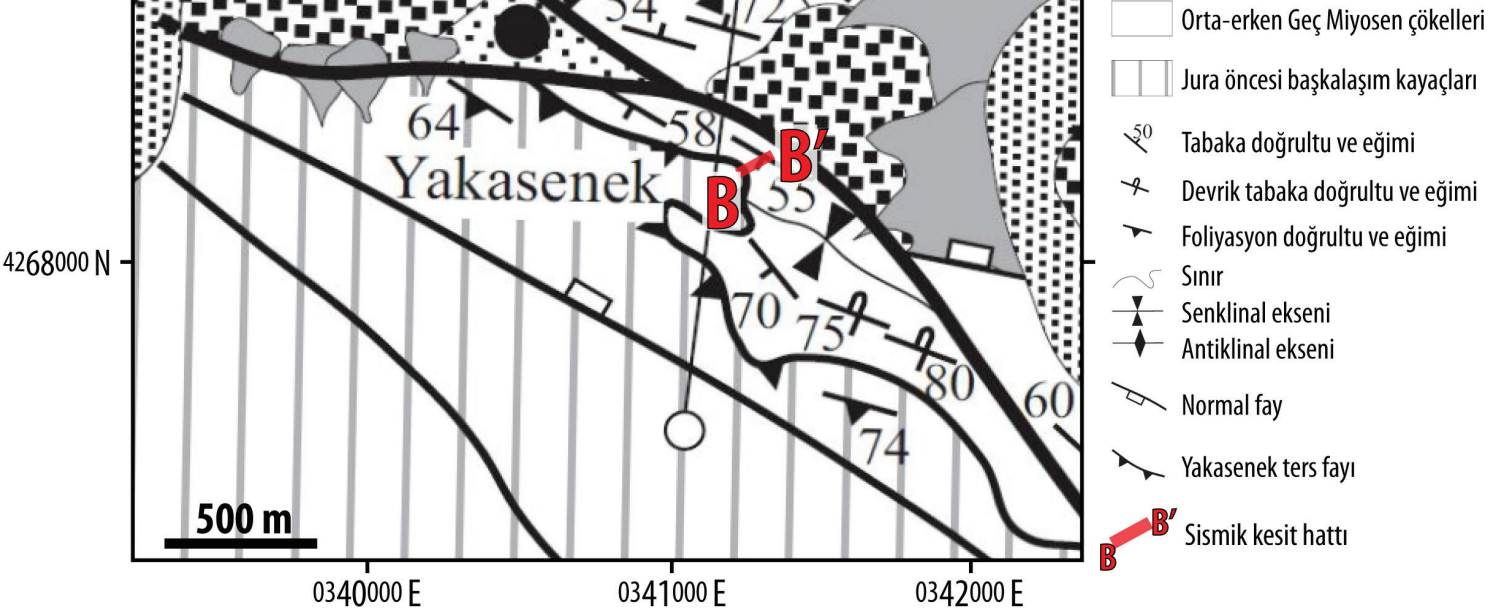

Șekil 3. a) İnceleme alanının jeoloji haritası (Kaya, 2008 ve Kaya vd., 2009'dan yeniden çizilerek alınmıștır). b) Varolduğu öne sürülen Yakasenek Ters Fayı'nı gösteren jeolojik harita (Koçyiğit ve Özacar, 2003'den kesilerek alınmıștır). Aynı bölgeye ait bu iki farklı harita karșılaștırma amacıyla alt alta verilmiștir. Koordinatlar UTM, ED50 sistemine göredir.

Figure 3. a) Geological map of the study area (after Kaya, 2008 and Kaya et al., 2009). b) Geological map showing the so-called Yakasenek Reverse Fault (after Koçyiğit and Özacar, 2003). These two different maps of the same area have been given one under the other for comparison. Coordinates are UTM, ED50. 
KKD

GGB

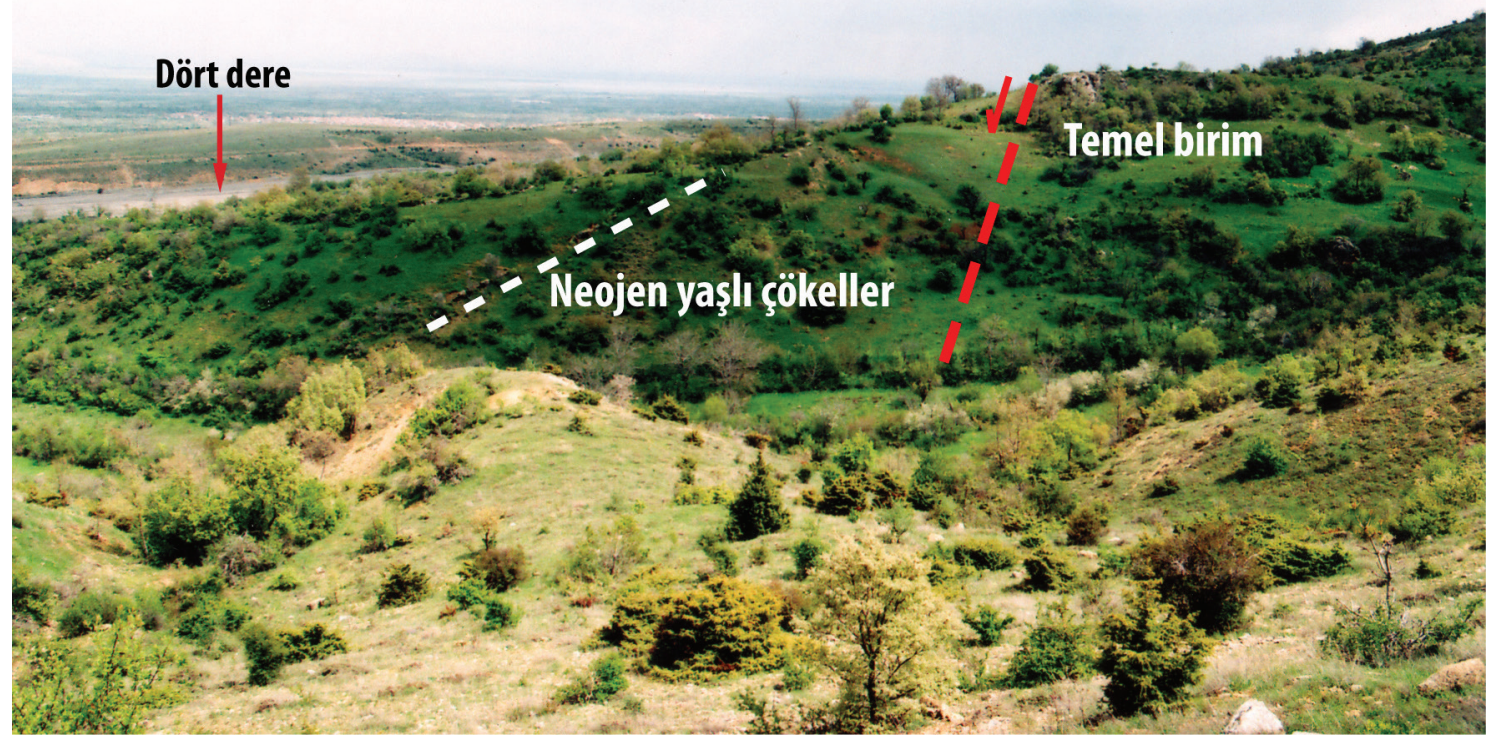

Șekil 4. Temel birim ile Neojen yașlı çökeller arasındaki normal faylı sınır (Kesikli kırmızı çizgi normal faylı sınırı, kesikli beyaz çizgi ise kuzeye eğimli Neojen tabakalarını göstermektedir). Lokasyon için Șekil 3a'ya bakınız.

Figure 4. Normal fault boundary between the basement and the Neogene sedimentary rocks (Dashed red and white lines represent the normal fault boundary and the $N$-dipping Neogene strata, respectively). See Figure $3 a$ for location.

\begin{tabular}{|c|c|c|c|c|c|c|}
\hline $\begin{array}{l}\text { Üst } \\
\text { Sistem }\end{array}$ & \multicolumn{2}{|c|}{ Sistem } & Seri & $\begin{array}{l}\text { Atalay } \\
\text { (1973) }\end{array}$ & $\begin{array}{c}\text { Demirkol vd. } \\
\text { (1977) }\end{array}$ & $\begin{array}{l}\text { Koçyiğit vd. } \\
\quad(2000)\end{array}$ \\
\hline \multirow[b]{2}{*}{$\underline{1}$} & \multirow{2}{*}{\multicolumn{2}{|c|}{$\begin{array}{l}\text { KUVA- } \\
\text { TERNER }\end{array}$}} & HOLOSEN & Yeni alüvyon & Yeni alüvyon & Alüvyon \\
\hline & & & PLEYISTOSEN & Eski alüvyon & Eski alüvyon & Taşköprü \\
\hline \multirow{3}{*}{$\underset{0}{2}$} & \multirow{3}{*}{ 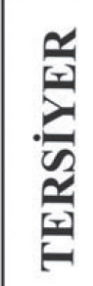 } & \multirow{2}{*}{ 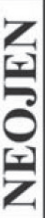 } & PLIYOSEN & $\begin{array}{l}\text { Kil,silt, } \\
\text { kum,çakıl }\end{array}$ & $\begin{array}{l}\text { Yarıkkaya } \\
\text { formasyonu } \\
\text { Kireçtaşı üyesi }\end{array}$ & $\begin{array}{l}\text { Doğancık } \\
\text { formasyonu }\end{array}$ \\
\hline & & & MIYOSEN & $\begin{array}{l}\text { Sarı gölsel } \\
\text { kireçtaş1 }\end{array}$ & & $\begin{array}{l}\text { Köstere } \\
\text { formasyonu }\end{array}$ \\
\hline & & \multicolumn{2}{|c|}{ PALEOJEN } & & & \\
\hline \multirow{3}{*}{ 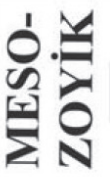 } & \multicolumn{3}{|c|}{ KRETASE } & & & \\
\hline & \multicolumn{3}{|c|}{ JURA } & \multirow{3}{*}{$\begin{array}{l}\text { Temel } \\
\text { Metamorfik } \\
\text { birim }\end{array}$} & & \\
\hline & & TRI & YAS & & & \\
\hline \multicolumn{4}{|c|}{ PALEOZOYIKK } & & $\begin{array}{l}\text { Temel } \\
\text { Metamorfik } \\
\text { birim }\end{array}$ & $\begin{array}{l}\text { Metamorfik } \\
\text { birim }\end{array}$ \\
\hline
\end{tabular}

Șekil 5. Çalıșma alanı ve yakın çevresinde değișik araștırmacılar tarafından belirlenmiș stratigrafik birimlerin karșılaștırması.

Figure 5. Comparison of the stratigraphic units in the study area and its surroundings determined by various researchers. 


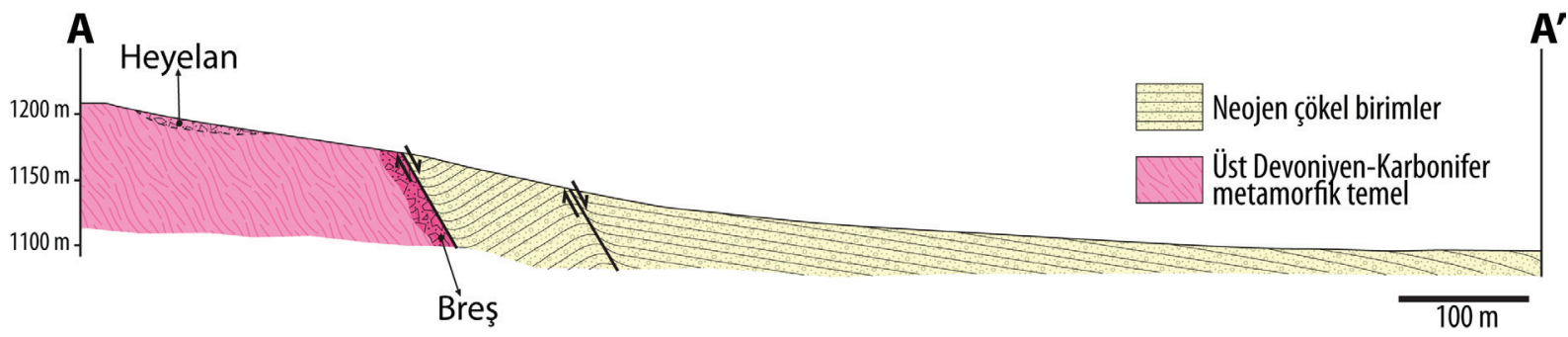

Șekil 6. A-A' kesit hattından alınmıș jeolojik kesit. Lokasyon için Șekil 3a'ya bakınız.

Figure 6. Geological cross-section from the A-A' line. See Figure 3a for location.

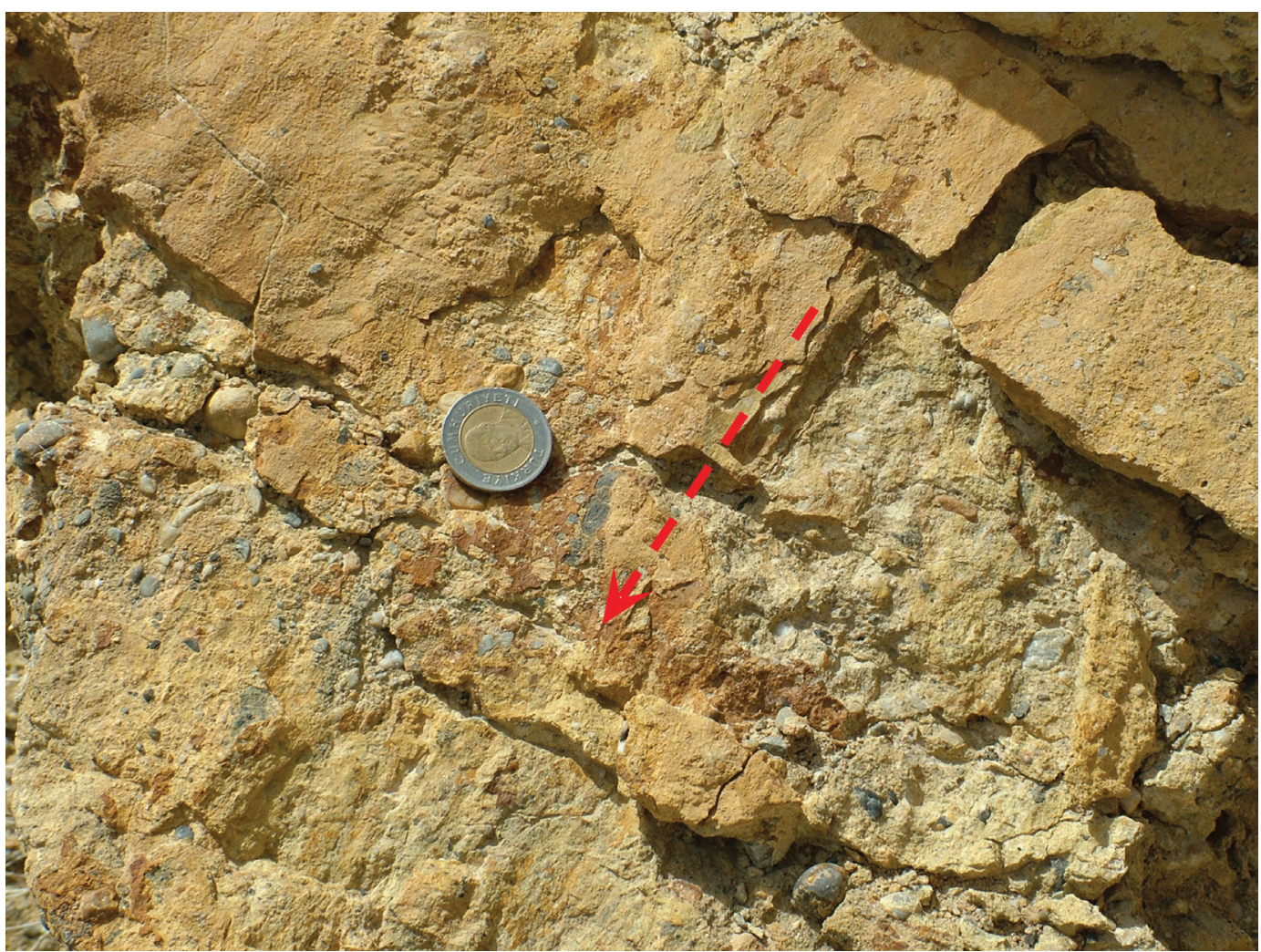

Șekil 7. Neojen yașlı birim içerisinde gelișmiș normal faylanmanın kayma düzleminden yakın görünüm. Her ne kadar düzlem üzerindeki fay çizikleri belirgin olarak gözlenmese de ok tavan bloğun hareket yönünü göstermektedir.

Figure 7. A close view from the slickenside of the normal fault in the Neogene unit. Although the slickenlines on the fault surface are not clearly observed, the arrow indicates the movement direction of the hanging wall.

ile Neojen çökeller arasındaki sınırda düzlemin eğim yönünü belirlemek için bir sismik yansıma çalıșması gerçekleștirilmiștir. Șekil 3a'da görülen B-B' hattı boyunca 'sismik ıșın yönlendirme' yöntemiyle sismik kesit elde edilmiștir.

En genel anlamıyla sismik yöntem, yapay sarsıntılarla olușturulan sismik dalgaların yer içerisinde ilerleyerek farklı derinliklerdeki tabakalardan yansıyıp yeryüzüne geri dönmesi ve belli bir hat boyunca dizilmiș jeofon adı verilen alıcılarla bu dalgaların kaydedilmesidir. Günümüzde sismik yöntemler yerin stratigrafik ve tektonik özelliklerinin belirlenmesi, jeotermal aramalar, petrol ve kömür araștırmaları, tuz ve su araștırmaları, jeolojik yatakların araștırıması, arkeolojik yapıların araștırılması, mühendislik çalıșmaları amacıyla kullanılmaktadır. 
Bir sismik yansıma yöntemi için gereken aletler, sismik dalgaları üreten bir enerji kaynağı, sismik dalgaları yüzeyde algılayan jeofonlar ve bu alıcılara gelen bilgileri kaydeden bir sismik kayıtçıdan ibarettir.

Sismik yöntemlerde kullanılan enerji kaynakları dinamit, ağırlık düșürme, sismik vibratör vb. olabilir. Bir profil boyunca titreșim ya da yapay sarsıntıların olușturulabilmesi için bu enerji kaynaklarından herhangi birinin kullanıması ișlemi 'atıș' olarak adlandırılır. Bu çalıșmada sismik atıșlar balyozun, madeni bir levhaya vurulmasıyla elde edilmiștir. Bu atıșlar ile yer içerisine gönderilen ve fay yüzeyinden yansıyan dalgalar yüzeyde bir hat boyunca dizilen jeofonlar tarafından algılanırlar (Șekil 9). Yeraltındaki yapıların yanal çözünürlüğünü arttırmak için jeofon ve atıș aralıkları genellikle kısa tutulmaktadır. Çünkü atıș aralığının kısa mesafeli olması yer altından daha fazla bilgi alınması demektir. Jeofonların sayısı 24, 48 ya da 96 olabileceğinden kullanılan sismik cihaz da 24, 48 ya da 96 kanallı olabilmektedir.

Sahada toplanan sismik veri daha sonra bir dizi veri-ișlem așamasından geçirilmekte ve böylece veri kalitesi yüksek bir sismik kesit elde edilmektedir.

Jeofizik çalıșmalar Șekil 3a üzerindeki B-B' hattı boyunca temel metamorfik birim ile Neojen yașı çökeller arasında önceki araștırıcılar tarafından Yakasenek Ters Fayı olarak tanımlanmıș dokanak üzerinde uygulanmıștır (Șekil 10).
Fay eğim açısının belirlenmesinde 'sismik ıșın yönlendirme' tekniğine ait arazi düzeni ve ilgili zaman-uzaklık grafikleri Șekil 11'de gösterilmiștir. Atıșlar serimlerin fay mostrasına uzak uçlarında yapılmıștır. Fay yüzeyinden yansıyarak gelen ve fayla ilgili bilgi içeren sismik sinyalleri güçlendirmek için, her serimde, araları 1'er m mesafeli 8 atıș yapılmıștır. Alıcılar arasındaki uzaklıklar değișken olup, fay mostrasına yaklaștıkça bu aralıklar 4 m' den bașlayarak $2 \mathrm{~m}$, $1 \mathrm{~m}$ ve 0.5 m'ye kadar azalmaktadır. Böylece faya yakın yerlerden daha yoğun bilgi alınmıștır. Sismik enerjinin ilk atıș noktasından son jeofona kadar ulașabilmesi için, ilk atıșla fay mostrası arasındaki uzaklık 50 metre ile sınırlı tutulmuștur.

Ölçümlerde 24 adet 26 Hz'lik S-jeofonu kullanılmıștır. Örnekleme aralığı 0.5 milisaniye, kayıt uzunluğu 1 saniyedir. Kayıt sırasında herhangi bir süzgeç kullanılmamıștır. Fay mostrasına dik doğrultuda ve fayın her iki bloğunda ayrı ölçümler alacak șekilde, biri diğerinin uzantısı iki sismik profil tasarlanmıștır (Șekil 11). Her iki profilde S-jeofonları fay mostrasına doğru yönlendirilmiștir.

Sismik atıșlar 12 kg'lık bir balyozla, düșeyle yaklașık 20-30 derece açı yapan bir madeni levhaya vurularak gerçekleștirilmiștir (Șekil 9). Sismik atıșlar için asimetrik $\mathrm{V}$ biçimli çukurlar açılmıștır. Her sismik atıș için, sinyali güçlendirmek amacıyla, levha üzerine aynı șekilde 3 kez vurularak 3 düșey yığma yapılmıștır. Eğik bal-

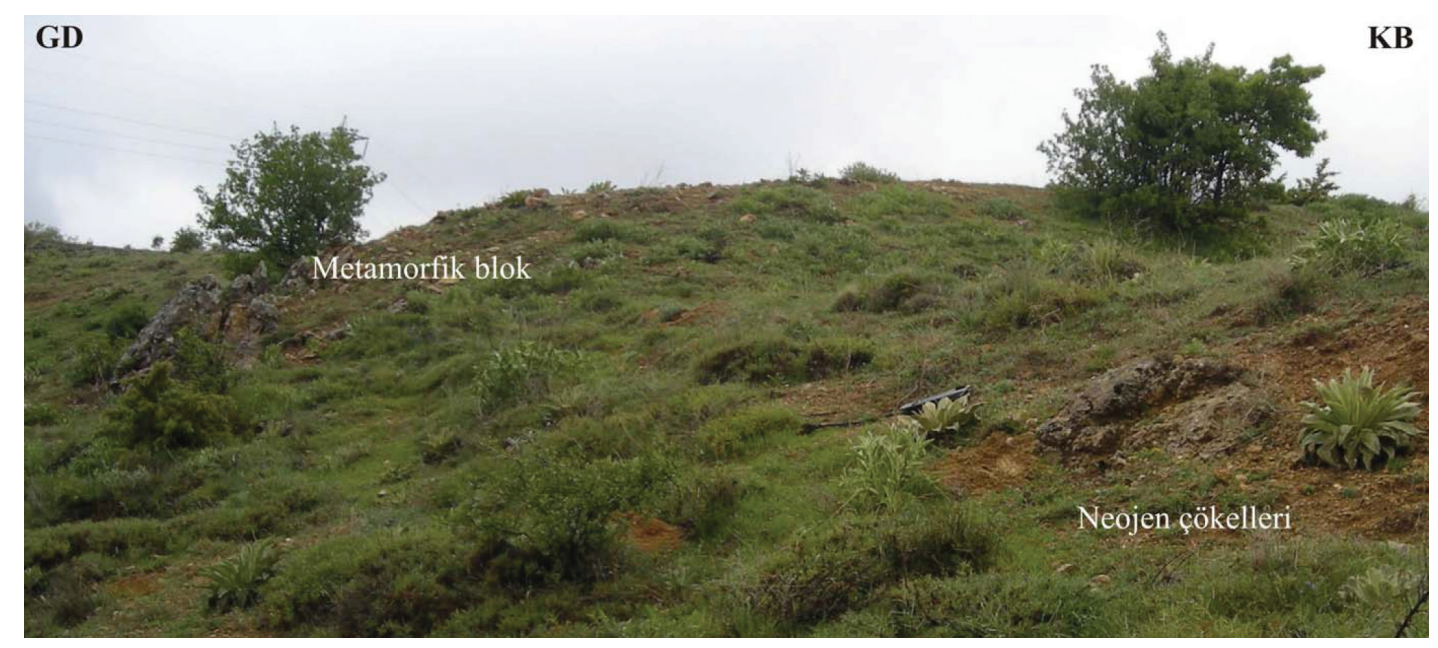

Șekil 8. Heyelanlı bölgede Neojen çökelleri üzerindeki metamorfik kayaç blokları.

Figure 8. Metamorphic rock blocks on the Neogene sediments in the landslide area. 


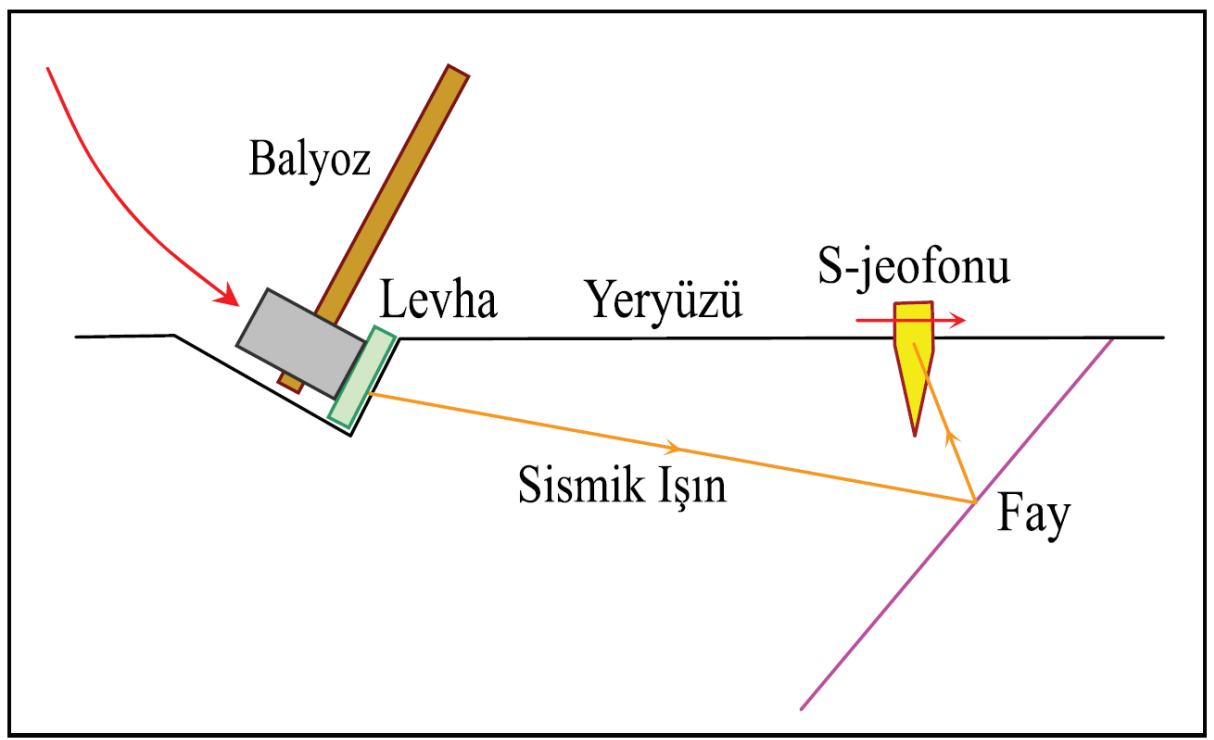

Șekil 9. 'Sismik ıșın yönlendirme' yöntemiyle bir sismik atıșın gerçekleștirilmesi. S-jeofonları faya doğru yönlendirilmiștir.

Figure 9. Performing a seismic shot using the 'seismic beam steering' method. S-geophones are oriented towards the fault.

yoz vurușları, sismik enerjinin yönlendirilmesini sağlamaktadır. Bu yöntemle așırı eğimli jeolojik yapılardan sismik sinyal alınması mümkündür. Sismik yansıma verilerinin ișlenmesi așamasında rüzgâr gürültüsünü bir miktar bastırmak için 5-10-140-150 Hz aralıklı band-geçișli bir sayısal süzgeç kullanılmıștır.

Șekil 11'de kırmızı ile gösterilen zaman-uzaklık eğrisi (hiperbol), fay yüzeyinden gelen yansımaya aittir. Sismik ıșın geometrisi ve ilgili bağıntılar EK'te verilmiștir.

Sismik hattın güneybatı ucundan fay yüzeyine gönderilen ıșın demeti yolculuğu boyunca herhangi bir yüzeye rastlamadığı için yoluna devam etmektedir. Bu durumda sismik atıșlara ait sismik profil ayrıntılarına bakıldığında fayın güneybatı bloğunda yer alan S-jeofonlarının herhangi bir yansıma ve saçılma kaydetmediği görülür (Șekil 12).

Diğer taraftan sismik hattın kuzeydoğu ucundan fay yüzeyine gönderilen ıșınların bir yüzeye çarparak geri döndükleri ve böylece kuzeydoğu bloktaki S-jeofonlarının fay yüzeyinden yansıyan saçılmaları kaydettiği görülür (Șekil 12). Sağ sismik kesitler incelendiğinde, fay yüzeyine gönderilen her ıșın demetinin yüzeyden yansıyıp dönerken diğer ıșın demetini etkilediği görülür. Oysaki ıșınlar arasındaki bu sismik olay sol sismik yansıma kesitinde gözlenmemektedir. Dola- yısıyla fayın kuzeydoğuya eğimli olduğu belirgindir. Ayrıca sismik profil ayrıntılarına bakıldığında fay açısı yaklașık $60^{\circ}$ lik bir değer sunmaktadır.

\section{TARTIȘMA VE SONUÇLAR}

Yakasenek Ters Fayı'nın varolduğu ileri sürülen bölgede gerçekleștirilen arazi çalıșmaları ve uygulanan 'sismik ıșın yönlendirme' yöntemi ile buradaki tektonik hat $60^{\circ}$ kuzeydoğuya eğimli olarak belirlenmiștir. Sismik profil ayrıntılarına bakıldığında sismik olayların sağ sismik kesitlerde yani fayın kuzeydoğu bloğunda gözlenmesi buradaki fayın kuzeydoğuya eğimli olduğunu göstermektedir. Fayın güneybatının aksine kuzeydoğuya eğimli olarak saptanması, bölgede MiyosenPliyosen'de sıkıșmanın varlığını ortaya koyan ve iki evreli genișleme modelini destekleyen Yakasenek Ters Fayı'nın bulunmadığını göstermiștir. Bölgede yapılan arazi gözlemlerinde de ters faya yönelik herhangi bir veriye rastlanmamıștır; ancak geniș bir alanda yanlıș bir yorumla ters faylanma olarak değerlendirilebilecek heyelanlı bir bölge tespit edilmiștir (Karșılaștırma için Șekil 3'e bakınız). Varlığı jeofizik veri ile de desteklenen kuzeydoğuya eğimli fay düzlemi olasilıkla normal fay bileșenli Sultandağı Fayı'na aittir ve bu bölgedeki genișlemeli tektonik rejimin sıkıșmalı bir dönemle bölünmediğini göstermektedir. 

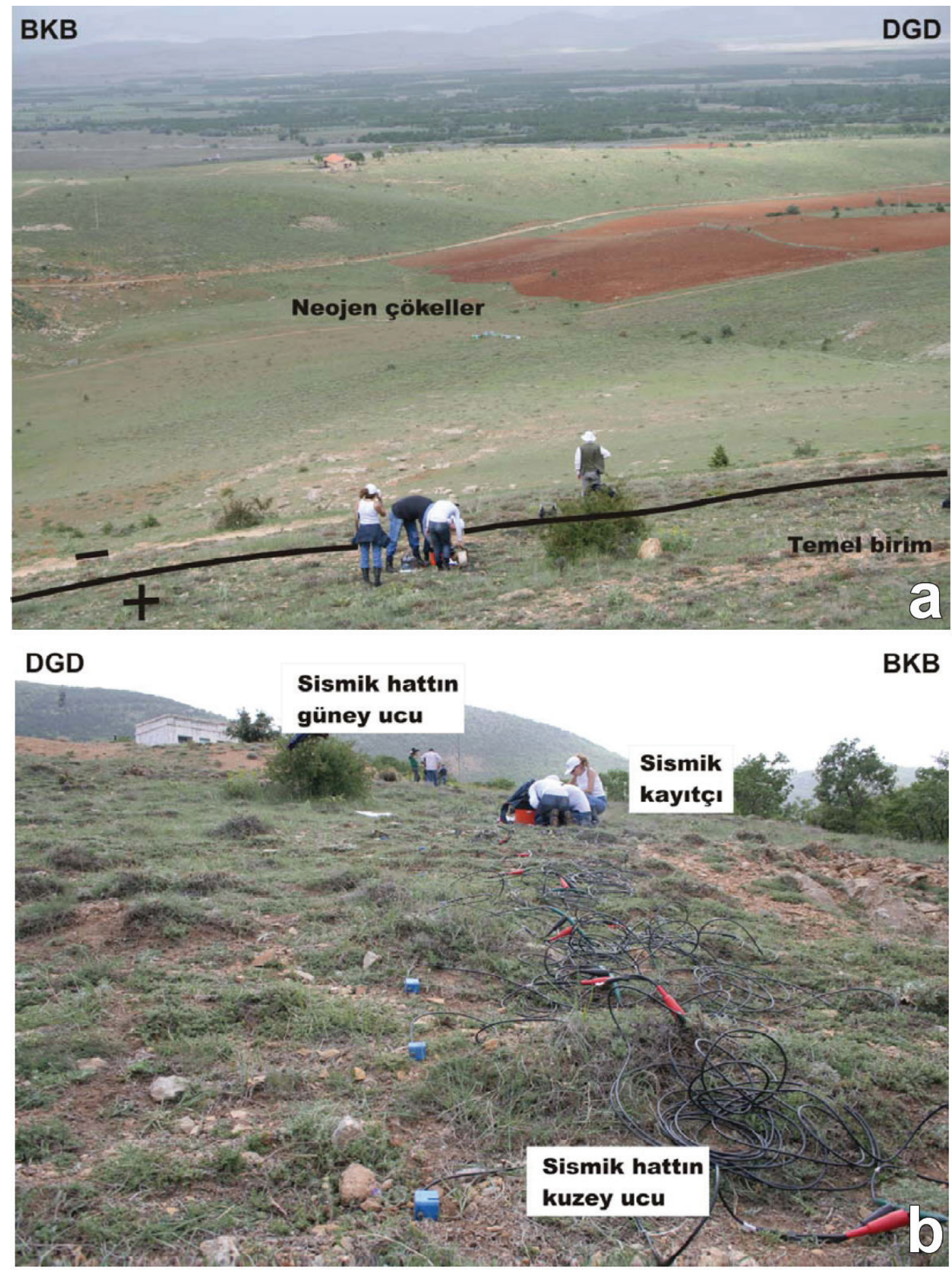

Șekil 10. a) 'Sismik ıșın yönlendirme' yönteminin uygulandığı, temel bașkalașım kayaçları ile Neojen çökel birimleri arasındaki kuzeydoğuya eğimli tektonik sınııı arazi görüntüsü. b) Sismik profil hattının arazideki görüntüsü.

Figure 10. a) A field view from the 'seismic beam steering' method applied to the $\mathrm{N}$-dipping tectonic boundary between the basement metamorphic rocks and the Neogene sedimentary units. b) Field view of the seismic profile line. 


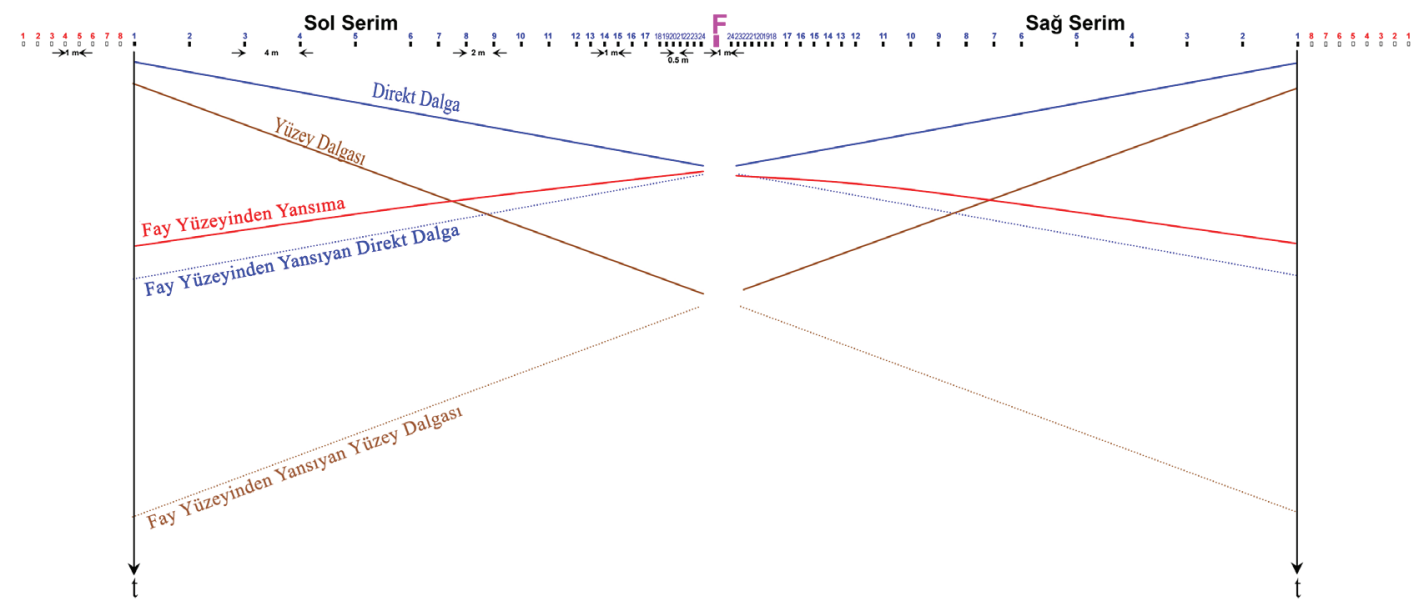

Șekil 11. Fay eğim açısının belirlenmesinde 'sismik ıșın yönlendirme' yönteminin uygulanıșı. En üstte arazi düzeni görülmektedir. İçi boș kutucuklar atıș istasyonlarını, siyah kutucuklar alıcı istasyonlarını göstermektedir. Ortadaki 'F' harfi fayın mostra verdiği noktadır. Birbirlerine bakan siyah oklar aralık uzaklıklarını belirtmektedir. Alt bölümde sol ve sağ serimlere ait zaman-uzaklık grafikleri görülmektedir. Değișik renklerle çizilen eğriler üzerine, aynı renklerle ilgili sismik dalga fazları yazıııștır. Fay Yüzeyinden Yansıma bir hiperboldur. Öte yandan, Direkt Dalga, Fay Yüzeyinden Yansıyan Direkt Dalga, Yüzey Dalgası, Fay Yüzeyinden Yansıyan Yüzey Dalgası birer doğru parçalarıdır.

Figure 11. Applying the 'seismic beam steering' method for determine the fault dip angle. Field arrangement is seen at the top. Empty and filled boxes represent shot and receiver stations, respectively. ' $F$ ' in the middle represents the fault outcrop. Black arrows indicate distances. Time-distance graphics of the left (sol serim) and right (sağ serim) seismic lines are seen at the lower part. Names of seismic wave phases are written on the various coloured curves with the same colours. Reflection from the Fault Plane (Fay Yüzeyinden Yansıma) is a hyperbole. On the other hand, Direct Wave (Direkt Dalga), Reflected Direct Wave from the Fault Plane (Fay Yüzeyinden Yansıyan Direkt Dalga), Surface Wave (Yüzey Dalgası), Reflected Surface Wave from the Fault Plane (Fay Yüzeyinden Yansıyan Yüzey Dalgası) are straight lines.

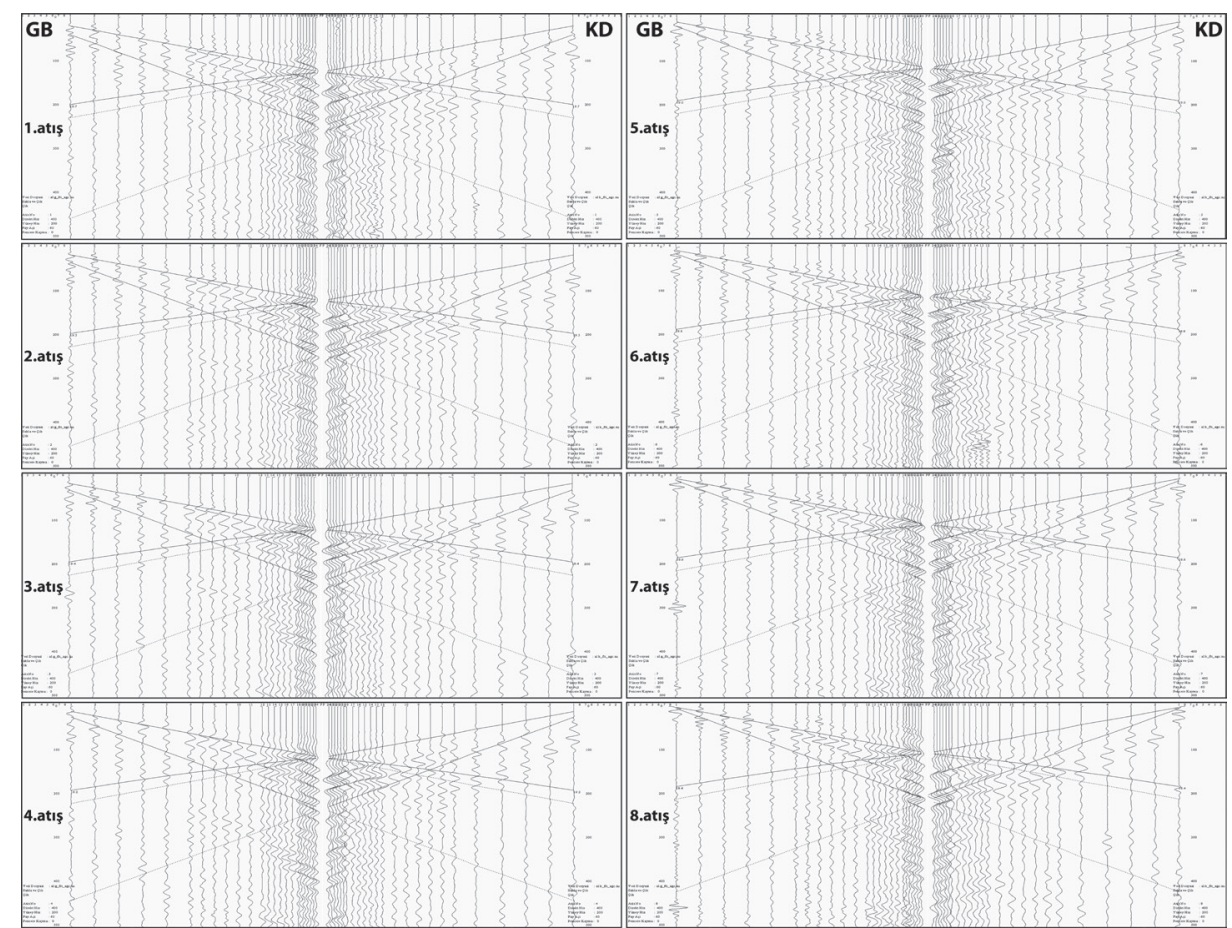

Șekil 12. Atıșlara ait sismik profil ayrıntısı (Soldaki ortak-uzaklık sismik yansıma kesiti fayın güneybatı bloğundan, sağdaki ortak-uzaklık sismik yansıma kesiti fayın kuzeydoğu bloğundan elde edilmiștir).

Figure 12. Seismic profile details of the shots (Common-distance seismic reflection profiles in the left side and the right side are obtained from the southern block and the northern block of the fault, respectively). 


\section{KATKI BELIRTME}

Yazarlar yapıcı katkıları ve olumlu görüșleri nedeniyle Mehmet Tekin Yürür ve adı belirtilmemiș diğer hakeme teșekkür ederler.

\section{KAYNAKLAR}

Akyüz, H.S., Uçarkuș, G., Șatır, D., Dikbaș, A. ve Kozacı, Ö., 2006. 3 Șubat 2002 Çay depreminde meydana gelen yüzey kırığı üzerinde paleosismolojik araștırmalar. Yerbilimleri, 27(1), 41-52.

Atalay, i., 1973. Sultandağları ile Akșehir ve Eber Gölleri havzalarının strüktüral, jeomorfolojik ve toprak erozyonu etüdü. Doktora tezi (basılmıș), Yeni Desen Mat., Ankara.

Atalay, i., 1975. Tektonik hareketlerin Sultandağları'nın jeomorfolojisine olan etkileri. Türkiye Jeoloji Kurumu Bülteni, 18, 21-26.

Barka, A. and Reilinger, R., 1997. Active tectonics of the Eastern Mediterranean region: deduced from GPS, neotectonic and seismicity data. Annali di Geofisica, 40, 587-610.

Bașokur, A.T., Gökten, E., Seyitoğlu, G., Varol, B., Ulugergerli, E.U., Ișık, V., Candansayar, E. ve Tokgöz, E., 2002. Jeoloji ve jeofizik çalıșmalar ıșığında 03.02.2002 Çay (Afyon) depremi'nin mekanizması, hasarın nedenleri ve bölgenin deprem etkinliği. Ankara Üniversitesi Mühendislik Fakültesi Yayını, 56s.

Boray, A., Șaroğlu, F. ve Emre, Ö., 1985. Isparta büklümü'nün kuzey kesiminde DoğuBatı daralma için bazı veriler. Jeoloji Mühendisliği, 23, 9-20.

Bozkurt, E. and Rojay, B., 2005. Episodic, twostage Neogene extension and shortterm intervening compression in Western Turkey: field evidence from the Kiraz Basin and Bozdağ Horst. Geodinamica Acta, 18, 299-316.

CCGM, 2013. Akdeniz'in jeodinamik haritası, http://ccgm.free.fr, 07/2013'te ulașl|miștır.

Demirkol, C., Sipahi, H., Çiçek, S., Barka, A. ve Sönmez, Ș., 1977. Sultandağının stra- tigrafisi ve jeoloji evrimi. Maden Tetkik ve Arama Genel Müdürlüğü Raporu, No: 6305, Ankara.

Emre, Ö., Duman, T.Y., Doğan A., Özalp, S., Tokay, F. and Kușçu, I.., 2003. Surface faulting associated with the Sultandağı earthquake (Mw 6.5) of 3 February 2002, southwestern Turkey. Seismological Research Letters, 74(4), 382-392.

Emre, T. and Sözbilir, H., 2007. Tectonic Evolution of the Kiraz Basin, Küçük Menderes Graben: Evidence for compression/ uplift-related basin formation overprinted by extensional tectonics in west Anatolia. Turkish Journal of Earth Sciences, 16, 441-470.

Güngör, T., 2013. Kinematics of the Central Taurides during Neotethys closure and collision, the nappes in the Sultan Mountains, Turkey. International Journal of Earth Sciences, DOI 10.1007/s00531012-0854-4.

Kaya, O., Ünay, E., Göktaș, F. and Saraç, G., 2007. Early Miocene stratigraphy of central west Anatolia, Turkey: implications for the tectonic evolution of the eastern Aegean area. Geological Journal, 42, 85-109.

Kaya, S., 2008. Sultandağı Fayı'nın Neojen devrindeki evrimi. Yüksek Lisans tezi, Ankara Üniversitesi, Fen Bilimleri Enstitüsü, Ankara (yayımlanmamıș), 68s.

Kaya, S., Can, A.Z., Esat, K., Ekincioğlu, E.E., Akkaya, I.., Ișık, V., Kaypak, B., Aldaș, G.U., Ecevitoğlu, B. ve Seyitoğlu, G., 2009. Afyon-Akșehir grabeninde Yakasenek ters fayı olarak tanımlanan yapı üzerinde jeolojik ve jeofiziksel gözlemler: İki evreli graben modeli için bir test. 62. Türkiye Jeoloji Kurultayı Bildiri Özleri Kitabı, Ankara, s.206-207.

Koçyiğit, A., 1984. Güneybatı Türkiye ve yakın dolayında levha içi yeni tektonik gelișim. Türkiye Jeoloji Kurumu Bülteni, 27, 1-16.

Koçyiğit, A., Yusufoğlu, H. and Bozkurt, E., 1999. Evidence from the Gediz graben for episodic two-stage extension in western Turkey. Journal of the Geological Society, London, 156, 605-16. 
Koçyiğit, A., Ünay, E. and Saraç, G., 2000. Episodic graben formation and extensional neotectonic regime in west central Anatolia and the Isparta Angle: a case study in the Akșehir-Afyon graben, Turkey. In: Bozkurt, E., Winchester, J.A. and Piper, J.D.A. (eds), Tectonics and Magmatism in Turkey and the Surrounding Area. Geological Society, London, Special Publications, 173, 405-421.

Koçyiğit, A. and Özacar, A.A., 2003. Extensional neotectonic regime through the NE edge of the outer Isparta Angle, SW Turkey: New field and seismic data. Turkish Journal of Earth Sciences, 12, 67-90.

Koçyiğit, A., 2005. The Denizli graben-horst system and the eastern limit of western Anatolian continental extension: basin fill, structure, deformational mode, throw amount and episodic evolutionary history, SW Turkey. Geodinamica Acta, 18(3-4), 167-168.

Öcal, H., Alan, İ., Balcı, V. ve Keskin, H., 2011. 1/100.000 ölçekli jeoloji haritası: Afyon-K26 paftası. Maden Tetkik ve Arama Genel Müdürlüğü, Ankara.

Öğdüm, F., Kozan, T., Bircan, A. ve Bozbay, E., 1989. Sultandağları'nın tektonik jeomorfolojisi. Jeomorfoloji Dergisi, 17, 21-34.

Öğdüm, F., Kozan, T., Bircan, A., Bozbay, E. ve Tüfekçi, K., 1991. Sultandağları ve çevresindeki havzaların jeomorfolojisi ve genç tektoniği. Maden Tetkik ve Arama Genel Müdürlüğü Raporu, No: 9123, Ankara.

Özer, N., Altınok, Y. and Ceylan, S., 2007. Properties of the aftershocks sequences of the 2000 and 2002 earthquakes in Aksehir-Afyon graben, west-central Anatolia, Turkey. Natural Hazards, 40(3), 553-562.

Seyitoğlu, G. and Scott, B.C., 1991. Late Cenozoic crustal extension and basin formation in west Turkey. Geological Magazine, 128, 155-176.

Seyitoğlu, G. and Scott, B.C., 1996. The cause of $\mathrm{N}-\mathrm{S}$ extensional tectonics in western Turkey: tectonic escape vs. back-arc spreading vs. orogenic collapse. Jour- nal of Geodynamics, 22, 145-153.

Seyitoğlu, G., 1999. Discussion on evidence from the Gediz Graben for episodic two stage extension in western Turkey. Journal of the Geological Society, London, 156, 1240.

Seyitoğlu, G., Çemen, ì. and Tekeli, O., 2000. Extensional folding in the Alașehir (Gediz) graben, western Turkey. Journal of the Geological Society London, 157, 1097-1100.

Seyitoğlu, G., Tekeli, O., Çemen, I., Șen, Ș. and Ișik, V., 2002. The role of the flexural rotation/rolling hinge model in the tectonic evolution of the Alașehir graben, western Turkey. Geological Magazine, 139, 15-26.

Seyitoğlu, G., Alçiçek, M.C., Ișık, V., Alçiçek, H., Mayda, S., Varol, B., Yılmaz, I. and Esat, K., 2009. The stratigraphical position of Kemiklitepe fossil locality (Eșme, Ușak) revised: Implications for the Late $\mathrm{Ce}$ nozoic sedimentary basin development and extensional tectonics in western Turkey. Neues Jahrbuch für Geologie und Palaeontologie, 251, 1-15.

Seyitoğlu, G. and Ișık, V., 2009. Meaning of the Küçük Menderes graben in the tectonic framework of the central Menderes metamorphic core complex (western Turkey). Geologica Acta, 7(3), 323-331.

Șaroğlu, F., Emre, Ö. ve Boray, A., 1987. Türkiye'nin diri fayları ve depremselliği. Maden Tetkik ve Arama Genel Müdürlüğü Raporu, No: 8174, Ankara.

Șaroğlu, F., Emre, Ö. ve Kușçu, İ., 1992. Türkiye diri fay haritası, Maden Tetkik ve Arama Genel Müdürlüğü, Ankara, ölçek: 1/1 000000.

Șengör, A.M.C., 1980. Türkiye'nin neotektoniğinin esasları. Türkiye Jeoloji Kurumu yayını, $40 \mathrm{~s}$.

Șengör, A.M.C., Görür, N. and Șaroğlu, F., 1985. Strike-slip faulting and related basin formation in zones of tectonic escape: Turkey as a case study. The Society of Economic Paleontologists and Mineralogists, Special Publication, 37, 227264. 
Șengör, A.M.C. and Bozkurt, E., 2013. Layerparallel shortening and related structures in zones undergoing active regional horizontal extension. International Journal of Earth Sciences, 102(1), 101-119.

Taymaz, T. and Tan, O., 2001. Source parameters of June 6, 2000 Orta-Çankırı $(\mathrm{Mw}=6.0)$ and December 15, 2000 Sultandağ-Akșehir $(\mathrm{Mw}=6.0)$ earthquakes obtained from inversion of teleseismic $\mathrm{P}-$ and SH-body-waveforms. Symposia on seismotectonics of the northwestern Anatolia-Aegean and recent Turkish earthquakes, 96-107.

Ulusay, R., Aydan, Ö., Erken, A., Tuncay, E., Kumsar, H. and Kaya, Z., 2004. An overview of geotechnical aspects of the Çay-Eber (Turkey) earthquake. Engineering Geology, 73, 51-70.

Yürür, T., Köse, O., Demirbağ, H., Özkaymak, Ç. and Selçuk, L., 2003. Could the coseismic fractures of a lake ice reflect the earthquake mechanism? (Afyon earthquakes of 2 March 2002, Central Anatolia, Turkey). Geodinamica Acta, 16, 83-87.

\section{EK}

Sismik ıșın geometrisi ve ilgili bağıntılar:

$$
\begin{array}{ll}
\mathrm{x}_{\mathrm{F}} & \text { : Fay mostrasının } \mathrm{x} \text { koordinatı } \\
\mathrm{x}_{\mathrm{S}} & \text { : Kaynağın } \mathrm{x} \text { koordinatı } \\
\mathrm{x}_{\mathrm{R}} & \text { : Alıcının } \mathrm{x} \text { koordinatı } \\
\alpha & : \text { Fayın eğım açısı } \\
\mathrm{i} & : \text { Geliș açıSı } \\
\mathrm{x} & \text { : Yansıma noktasının x koordinatı } \\
\mathrm{z} & \text { : Yansıma noktasının z koordinatı } \\
r & : \text { Yolculuk mesafesi }
\end{array}
$$

a, b, c, d, e, f : Diğer yardımcı değișkenler

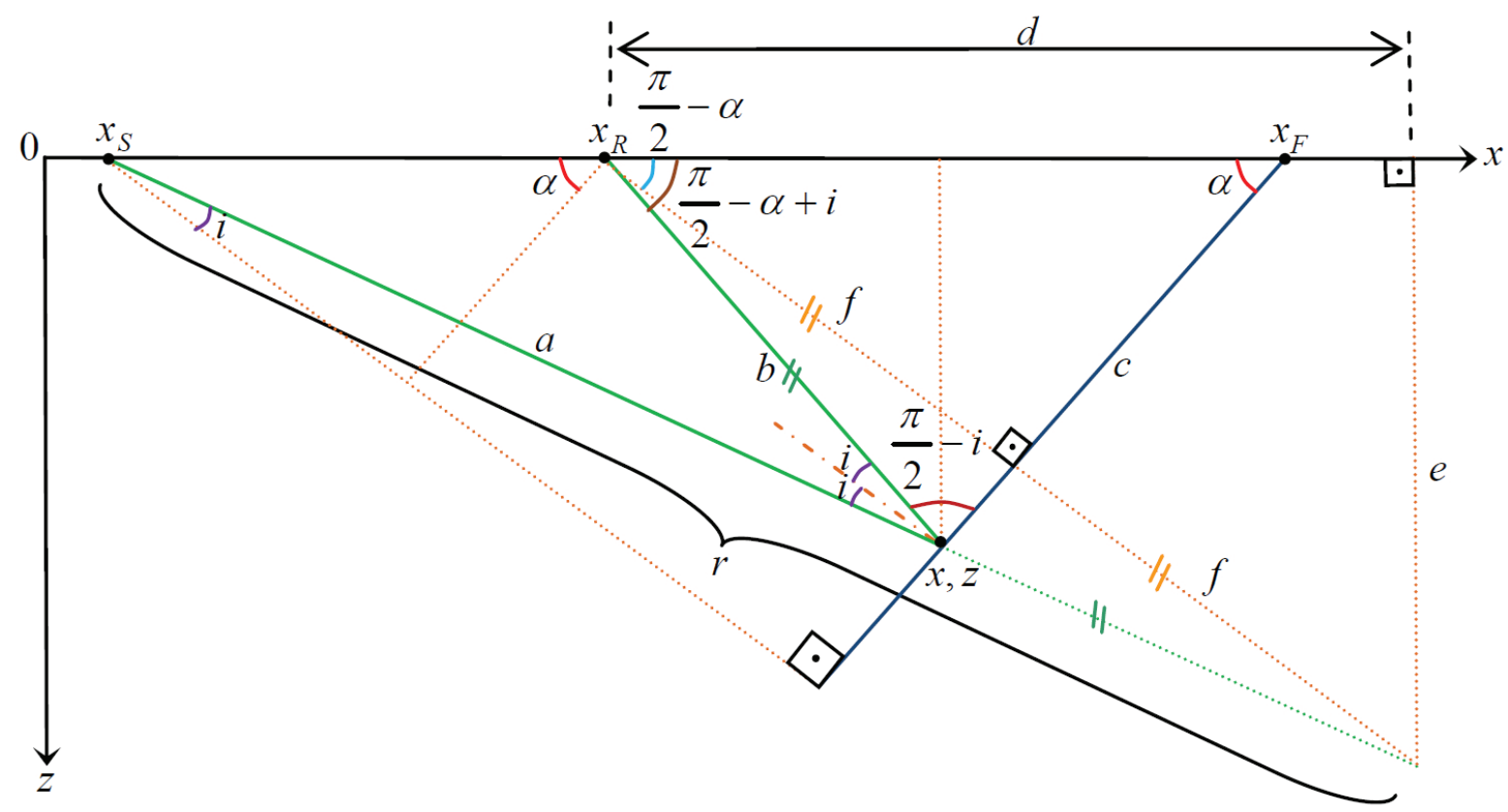

Fay düzleminden gelen yansımaya ait sismik ıșın geometrisi. 
Sismik ıșının kaynaktan çıkıp alıcıya ulașmasına kadar kat ettiği yolculuk mesafesine ait sayısal değer,

$$
r=\sqrt{\left(x_{R}-x_{S}+d\right)^{2}+e^{2}}=
$$

$\sqrt{\left[x_{R}-x_{S}+2\left(x_{F}-x_{R}\right) \sin ^{2} \alpha\right]^{2}+\left[\left(x_{F}-x_{R}\right) \sin 2 \alpha\right]^{2}}$

bağıntısı ile hesaplanmaktadır. Bu denklemde " $r$ " değerine ulașabilmek için " $d$ " ve "e" yardımcı değișkenlerinin bilinmesi gerekmektedir. Burada " d" değeri,

$$
d=2 f \cos \left(\frac{\pi}{2}-\alpha\right)=2\left(x_{F}-x_{R}\right) \sin ^{2} \alpha
$$

bağıntısı ile hesaplanırken, " e ” değeri de,

$$
e=2 f \sin \left(\frac{\pi}{2}-\alpha\right)=\left(x_{F}-x_{R}\right) \sin 2 \alpha
$$

bağıntısı ile belirlenmektedir. Bu bağıntılarda yer alan " $f$ " yardımcı değișkeninin değerine ise,

$f=\left(x_{F}-x_{R}\right) \sin \alpha$

bağıntısından ulașılmaktadır.

Yansıma noktasının sayısal değerlerini belirleyebilmek için ise "a", "b" ve "c" yardımcı değișkenlerinin belirlenmesi gerekmektedir. Bunun için,

$a \sin i+b \sin i=\left(x_{R}-x_{S}\right) \cos \alpha=(a+b) \sin i=r \sin i$

bağıntısından,

$$
\begin{aligned}
& \sin i=\frac{\left(x_{R}-x_{S}\right) \cos \alpha}{r} \operatorname{ve} \\
& \tan i=\frac{1}{\sqrt{\left[\frac{r}{\left(x_{R}-x_{S}\right) \cos \alpha}\right]^{2}-1}}
\end{aligned}
$$

değeri belirlenmektedir. "c" değerine ise,

$$
\frac{c}{\sin \left(\frac{\pi}{2}-\alpha+i\right)}=\frac{x_{F}-x_{R}}{\sin \left(\frac{\pi}{2}-i\right)}
$$

bağıntısından,

$$
c=\left(x_{F}-x_{R}\right) \frac{\cos (\alpha-i)}{\cos i}
$$

olarak ulașılmaktadır.

$\mathrm{Bu}$ değișkenler yardımıyla yansıma noktasının " $x$ " ve " $z$ " koordinat değerlerine,

$x=x_{F}-c \cos \alpha=$

$x_{F}-\left(x_{F}-x_{R}\right)\left[\cos ^{2} \alpha+\frac{\sin 2 \alpha}{2 \sqrt{\left[\frac{r}{\left(x_{R}-x_{S}\right) \cos \alpha}\right]^{2}-1}}\right]$

ve

$z=c \sin \alpha=$

$$
\left(x_{F}-x_{R}\right)\left[\frac{\sin 2 \alpha}{2}+\frac{1-\cos ^{2} \alpha}{\sqrt{\left[\frac{r}{\left(x_{R}-x_{S}\right) \cos \alpha}\right]^{2}-1}}\right]
$$

bağıntıları hesaplanarak ulașılabilmektedir. 